\title{
Eurostudia
}

\section{The "Ownership" of Churches: Ethnic, Racial, and Language Groups in U.S. Catholicism}

\section{Brett C. Hoover}

Volume 12, numéro 1, 2017

Religion and Space: Tensions and Negotiations in Everyday Life La religion et l'espace : tensions et négociations au quotidien Religion und Raum: Spannungen und Aushandlungen im Alltag

URI : https://id.erudit.org/iderudit/1041665ar

DOI : https://doi.org/10.7202/1041665ar

Aller au sommaire du numéro

\section{Éditeur(s)}

Le Centre canadien d'études allemandes et européennes

ISSN

1718-8946 (numérique)

Découvrir la revue

Citer cet article

Hoover, B. C. (2017). The "Ownership" of Churches: Ethnic, Racial, and Language Groups in U.S. Catholicism. Eurostudia, 12(1), 105-124. https://doi.org/10.7202/1041665ar
Résumé de l'article

Traditional understandings of ownership emphasize legal or economic property rights, but these conceptions come up short when examining faith communities in the United States context, where congregants often feel and act as "owners," regardless of legal property rights. International migration to the United States further complicates this "felt ownership" within faith communities, as distinct racial, ethnic, or language groups compete or cooperate around their claims of ownership. In those Roman Catholic faith communities known as "shared parishes," where multiple racial, ethnic, or language groups have separate worship and ministries but share facilities and leadership (Hoover 2014), the complex negotiations of sharing demonstrate the power dynamics between groups. A two-year case study of three such parishes in the Los Angeles area shows how the "felt ownership" of particular groups is privileged or limited by the various factors that shape the often asymmetrical power dynamics between the groups in U.S. society.
Tous droits réservés $@$ Le Centre canadien d'études allemandes et européennes, 2017
Ce document est protégé par la loi sur le droit d'auteur. L'utilisation des services d’Érudit (y compris la reproduction) est assujettie à sa politique d'utilisation que vous pouvez consulter en ligne.

https://apropos.erudit.org/fr/usagers/politique-dutilisation/ 


\title{
Brett C. Hoover
}

Loyola Marymount University

\begin{abstract}
:
Traditional understandings of ownership emphasize legal or economic property rights, but these conceptions come up short when examining faith communities in the United States context, where congregants often feel and act as "owners," regardless of legal property rights. International migration to the United States further complicates this "felt ownership" within faith communities, as distinct racial, ethnic, or language groups compete or cooperate around their claims of ownership. In those Roman Catholic faith communities known as "shared parishes," where multiple racial, ethnic, or language groups have separate worship and ministries but share facilities and leadership (Hoover 2014), the complex negotiations of sharing demonstrate the power dynamics between groups. A two-year case study of three such parishes in the Los Angeles area shows how the "felt ownership" of particular groups is privileged or limited by the various factors that shape the often asymmetrical power dynamics between the groups in U.S. society.
\end{abstract}

Over the last half century, international migration to and within the United States has transformed the demographic profile of many Christian groupings there, resulting in what one sociologist has called the "deEuropeanization of American Christianity" (Warner 1998: 4). While in mainline and Evangelical Protestant denominational families, such a declaration may seem premature, demographic change in the Roman Catholic Church suggests a clear trajectory away from the Church's Euro-American roots toward a more multicultural and especially Latino future (Pew Research Center 2015). Given the strong emphasis on lay leadership in U.S. faith communities (Warner 1994), even among Catholics (Warner 1998; Maines and McCallion 2004), such a transformation raises important questions about who "owns" the local parish, that is, not merely who holds legal title but which groups feel and take responsibility for parish facilities, spaces, and organizational life, both now and into the future. I argue here that the power

EUROSTUDIA - REVUE TRANSATLANTIQUE DE RECHERCHE SUR L'EUROPE 
relationships between such groups have a strong but complex impact on which groups stake a larger claim to ownership, which groups equitably share ownership, and why.

In the contemporary United States, asymmetrical power relationships between racial and ethnic groups frequently play out within Catholic parishes. This is, in part, because the Roman Catholic Church in the United States has addressed demographic change largely through the ad hoc development of shared parishes, that is, parishes where two or more ethnic, racial, or language groups retain distinct worship and ministry experiences but also negotiate a sharing of the worship space and other parish facilities. According to one study (Hoover 2014), negotiations usually center on quotidian matters such as custody and use of meeting rooms, parking lot usage, the allocation of parish resources, and the music and ritual of bilingual feast day liturgies. These negotiations occur under conditions of asymmetrical power shaped by the dynamics of the larger society. For example, in one parish shared by EuroAmerican and Mexican Catholic parishioners, the latter were repeatedly required by the parish staff to account for the condition of parish rooms they had just used, often over such picayune details as the alleged disappearance of a few pencils or the way in which library books were pushed in an inch all along the shelf. Such demands were never made on Euro-American parishioners, and members of the Mexican community vociferously complained about being constantly under such scrutiny (Idem: 130-131).

While ownership was not the focus of that study, the patterns of asymmetrical accountability show how power dynamics in a shared Catholic parish complicate parishioners' feelings and actions around their personal connection to and custody over the spaces they share. This present work, rooted in qualitative data from a two year case study of three shared Catholic parishes in Southern California, 1) looks more deeply at the theoretical question of ownership, making space for "felt ownership," 2) examines the history and context of ownership in U.S. Catholic parishes, 3) presents narrative data on the complex relationship between power dynamics and ownership in three parishes in Southern California, and 4) draws a few conclusions about the factors that shape that relationship.

\section{Theorizing Parish Ownership}


In their study on property rights systems, Bruce G. Carruthers and Laura Ariovich argue, "Ownership involves socially recognized economic rights. Property is that over which such rights obtain, and owners are those who possess the rights" (2004: 23). Yet viewing ownership exclusively in terms of economic rights proves inadequate when tackling ownership and responsibility in local faith communities. Sociologists of religion have argued since the 1990s that U.S. faith communities across religious traditions privilege the organizational form of the "congregation," a voluntary association of lay members who exercise significant leadership and control over the work and direction of the community (Warner 1994; Cadge 2008). Congregations engage people affectively and in functionally diffuse ways; clergy-led worship is only one of many activities, and most are supervised by a variety of lay people, the large majority of whom are not directly involved with the legal and economic structures of ownership, such as a vestry or board of trustees (Warner 1994). In short, a broad variety of community members possess a "felt" sense of ownership, which is then manifested in the way persons and groups take responsibility for the property and life of the faith community. This kind of ownership involves a strong personal attachment to church spaces and property, an emotional sense that these spaces belong to parishioners (Hoover 2014).

Sociologists have not devoted a great deal of attention to legal ownership or property rights (Carruthers and Ariovich 2004), let alone any more diffuse sense of felt ownership. At the same time, I would propose that the root questions of felt ownership do not differ significantly from those of economic property rights, questions of what can be owned, who owns it, how owners may use it, how their rights are enforced, and whether and how property may be transferred (Carruthers and Ariovich 2004). Somewhat more succinctly, Reeve (1986) proposes that ownership consists in the right to use property, the right to exclude others from it, and the right to sell or transfer it. In a parallel way, I argue that felt ownership in a religious context includes a perceived right to use a faith community's property and the expectation of a say in decisions made about the property's use (including who gets to use it and whether it may be alienated), all of this rooted in a strong emotional connection to the local faith community.

Finally, de facto congregationalism, the sociological view of all U.S. faith communities as tending toward the congregation as an organizational form, 
tends to privilege voluntarism-the personal choice to belong (Warner 1993). This lends itself to an account of felt ownership that focuses on the role of personal or group commitment. Yet research suggests that, especially for marginalized communities, perceptions about belonging and participation also depend on the welcome afforded by clergy and lay leaders of other groups (Wellmeier 1998; Marti 2009; Garces-Foley 2007; Hoover 2014). Case study data presented here demonstrate that the power dynamics between ethnic and racial groups within a Catholic parish shape the confidence and responsibility persons from different groups feel vis-à-vis parish facilities, spaces, and life. There is often an implicit, given quality to these power dynamics; parishioners rarely recognize their relative social advantages. In some cases, an equitable sense of ownership between groups emerges, shaped by the efforts of leaders, while in others a group's reduced sense of ownership echoes their marginal status within the parish and the larger society.

\section{The Historical and Legal Context of Catholic Ownership}

In the United States, state laws enable the corporate ownership of property through boards of trustees. This applies to both for-profit and not-for-profit organizations. The latter, which include churches and other religious organizations, enjoy various tax exemptions that encourage their formation for the public good. In the early decades of the nineteenth century, Catholic lay leaders could and did possess legal ownership for their parishes through a board of trustees, but a handful of contentious power struggles between clergy and laity persuaded Catholic bishops to concentrate legal ownership in their own hands. By the end of the nineteenth century, most parishes were legally owned by the diocesan bishop according to the "corporation sole" model, which continues to dominate (O'Toole 2008: 53-64). Corporation sole as a legal construct stipulates "that a single person, by virtue of holding a particular title, can become a corporation" (Dane 1998: 55).

Though bishops' own parish property by virtue of their office and the law, they practically have little to say about the regular use of that property, since most Catholic bishops oversee dozens or even hundreds of parishes. Efforts to sell, renovate, or acquire property do require the bishop's approval. According to church law, the priest pastor (called the "parish priest" outside of North America) operates as the bishop's delegate in the parish (Code of 
Canon Law 1985, canon 519); in practice, he makes or personally delegates most of the day-to-day decisions about the use of church property. In short, legal property rights for Catholic parishes in the United States are invested almost entirely in the bishop, a situation amply demonstrated in the recent closure of parishes by diocesan bishops in the U.S. Northeast and Midwest, often over the opposition of parishioners. Yet such interventions into local affairs, as devastating as they may be, occur more intermittently than regularly; most of the time, the bishop's ownership has more of a technical, abstract quality to it, while the locally present priest pastor operates with a sense of local control.

This is not to say that laypeople have had never had a say in the use of parish spaces. In the early history of Roman Catholicism in the United States, a dearth of priests enhanced lay control, even when the parish was not legally governed by lay trustees. German immigrant communities brought with them notions of local self-governance they transferred to their parishes. Polish parishes in the late nineteenth century were often incorporated and controlled by immigrant mutual aid societies. Gradually, various factors led to a more centralized, clerical control of parish life, including greater bureaucratic institutionalization, greater numbers of clergy, and an ideological focus on hierarchical authority as part of late nineteenth century resistance to modernity (Dolan 1992: 158-194). More recently, the changes in U.S. Catholicism associated with the Second Vatican Council (1962-65) have empowered lay Catholics to feel a renewed sense of ownership for their parishes (Maines and McCallion 2004). In studies of parish closures in Boston (Seitz 2011) and Detroit (Bridger and Maines 1998), parishioners made explicit reference to Vatican II teaching about the baptismal priesthood (also known as the priesthood of the faithful in contradistinction to the ministerial priesthood) and laypeople's shared responsibility for the church in asserting their right to oppose closures.

\section{Three Shared Parishes and Felt Ownership}

To explore more deeply the way ownership works in Catholic parish life today, I examine narrative data from a two-year ethnographic case study of three Southern California parishes, undertaken by the author and two 
graduate assistants with funding from the Congregational Studies Team. The three parishes included St. Martin de Porres, located in an affluent, coastal suburb. Historically, a Mexican mission parish, it was now dominated by Euro-Americans and the assimilated descendants of its historical Mexican community, tied together by their common worship and ministry in English. The parish was also home to a small immigrant, Spanish-speaking community. Holy Nativity, a predominantly African American Catholic parish, was situated in a poor and working class neighborhood of urban Los Angeles. A much smaller parish, it included a small pan-Latino immigrant community as well as the larger Black Catholic community. Finally, there was Queen of Heaven, an enormous parish situated in a majority Latino suburb of Los Angeles (80\% Hispanic according to the 2010 U.S. Census). With a reported weekend attendance of over 7000, Queen of Heaven hosted an Englishspeaking Mexican-American community, a Spanish-speaking Mexican and Central American immigrant community, and a small, more affluent Filipino community. The names of these parishes and their parishioners are pseudonyms, in order to maintain the confidentiality of informants' statements.

\begin{tabular}{|l|l|l|}
\hline St. Martin de Porres & Affluent suburb & $\begin{array}{l}\text { Euro-Americans and } \\
\text { assimilated Mexicans, } \\
\text { immigrant Latinos }\end{array}$ \\
\hline Holy Nativity & $\begin{array}{l}\text { Working class urban } \\
\text { neighborhood }\end{array}$ & $\begin{array}{l}\text { African Americans, } \\
\text { immigrant Latinos }\end{array}$ \\
\hline Queen of Heaven & Latino suburb & $\begin{array}{l}\text { English-speaking Mexican- } \\
\text { Americans, immigrant } \\
\text { Latinos, Filipinos }\end{array}$ \\
\hline
\end{tabular}

At each of the three parishes, one or two persons from each ethnic or racial group in the parish guided us through parish plant tours, telling stories and sharing information about parish life as they went. In addition, in English or Spanish (or a combination of the two), we conducted open-ended interviews with parish leaders and other intermediaries (14 total, 3-6 at each parish) and groups of people from the different ethnic, racial, or language groups (8 total, 2-3 per parish). Interview schedules focused on the relationships between the various groups in the parish and the factors that 
shaped them. We also observed Sunday masses at each parish for each of the groups. The resulting narrative data was coded using qualitative software.

Felt ownership was not the original focus of this research project at the three case study parishes, but it emerged in the qualitative data at all three as a consistent theme. This happened at different parishes, across ethnic, racial, and language groups, and in different types of conversations. During tours of the facilities at all three parishes, tour guides from the different communities all included historical details and colorful personal stories about events that took place in the different spaces. Most offered personal opinions about what went on in parish spaces, and several articulated a personal enthusiasm about and connection to the parish and its spaces. At two of the three parishes, multiple people from different communities described a family history at the parish, always including stories of reception of the sacraments in the church itself, some of those tales going back generations.

Parishioners at Queen of Heaven were perhaps the most articulate and direct about their sense of felt ownership. During an interview, the parish secretary noted, "People really take ownership of what they are doing here" (interview, July 17, 2012), though she acknowledged she spoke more of involved parishioners than casual massgoers. An elderly Filipina parishioner, relating the destructive impact of a previous pastor on the Filipino community added, "I just think the respect, it wasn't there...I myself have experienced that, but I fought, I fought like crazy... I say this is my parish" (interview, July 14, 2012). In a group interview with Spanish-speaking parishioners, one mother of two from Mexico asserted ownership over her parish because of the religious experiences she and her husband had undergone there, saying, "We have been on mission, but really the heart of us, for example, the heart of our marriage is here, in the parish. Because here was the place where it began, here that impulse to begin our understanding, to begin our road to encountering God. That was here" (interview, July 15, 2012).

The research focus of the three-parish study addressed the racial and ethnic power dynamics manifested in parish life at the three parishes. These dynamics had a clear impact on parishioners' sense of ownership. Three separate collective narratives, each reported from one of the three parishes, show how power dynamics complicated ownership. In no case was any group excluded from parish life, but in two of the three cases one group's sense of 
felt ownership was privileged while another's was limited. In both cases, the privileged group had greater numbers and greater relative social status. In the third parish, a more egalitarian relationship emerged in the narratives, in part because the numerical minority group was relatively affluent, in part because of the actions of pastoral leaders. In short, the narratives explored in the next three sections demonstrate how the felt ownership of religious space was influenced by distinct conditions within parish life: 1) the relative social status of different ethnic and language groups, 2) the racial history of faith communities in a particular context, and 3) cultural similarities in approaches to popular religious devotion.

\section{Material Space and Social Status}

The first narrative comes from St. Martin de Porres parish, the affluent suburban church with a history as a Mexican mission. At St. Martin's, according to the accounts of various people, the parish church demonstrated considerable wear as recently as a decade ago. Plans formed for a renovation, but parishioners accustomed to giving in small amounts failed to generate the pledges needed. To remedy the situation, the Catholic religious order granted custody of the parish by the local bishop appointed a new pastor, Fr. Steve, an older Anglo man with a big personality and a reputation as a fundraiser. $\mathrm{He}$ increased donations, secured funding to renovate the church completely, paid off the renovations, and purchased several additional buildings for meeting space. His account of the renovation demonstrated the confident felt ownership and real decision-making power of a priest pastor. During his tour through the worship space, we learned of statues he discarded when he deemed them to be of inferior quality, his clear preference for symbols over figures in church art, and the decision to imprint symbols from his own order's store of iconography around the worship space.

At the same time, in a separate interview with a group of Englishspeaking men who were parish leaders, it became clear that parishioners did have some role in that renovation, though a decidedly asymmetrical one by ethnicity. One of the men described the renovation thus:

"The Latin community is-and tell me if I'm wrong, is more of a subdued [group] and many times, I've been in situations where I've had to speak up more, and then they'll kind of stand back. Like the construction of the 
church, a remodel of the church is predominantly led by the Englishspeaking part of the community, but the Spanish community was involved, but I think the leadership was primarily English" (interview, July 8, 2014).

One of the other men in the interview pointed out that the Latino community had its leaders, directing activities in Spanish, but he agreed that administration and leadership more often resided more with the English speakers. "I would say, in that sense-again, from the administrative point of view, it's pretty much dominated by the English-speaking community" (interview, July 8, 2014). In fact, a younger Mexican priest and a fortyish Mexican immigrant did have a strong role in leadership and administration, but it appears true that persons from the Spanish-speaking community had less to say about the renovation and were more reluctant to assert their claims of ownership. As if to confirm the point, the English tour guide spoke enthusiastically about the church and the renovation, but the Spanish tour guide, also a long-time parishioner, only mentioned the cold, outdoor masses that occurred in the parking lot while the church was under construction.

\section{Symbolic Space and Racial History}

The second narrative complicating the relationship between power dynamics and ownership occurred at Holy Nativity parish, the historically African American Catholic parish. Here a controversy erupted not over physical space in the church but over the symbolic space of the church bulletin. The parish had a short identity statement in the weekly bulletin which began, "St. Martin de Porres is a Roman Catholic community rooted in a rich tradition of African American spirituality," and continued with a quote from Pope Paul VI about the gifts for the Church rooted in Africa. During a parish pastoral council meeting reviewing the statement, a proposal emerged to add an additional paragraph that described the parish as both African American and Hispanic. Some of the African American leadership of the parish felt confident that their unique brand of Catholicism would endure at the parish, and they wanted to acknowledge the long present Hispanic community's place. But others disagreed vehemently, and a more neutral proposal from Hispanic parishioners identifying the parish simply as "Roman Catholic" in the second paragraph went nowhere.

Interviews with multiple people regarding the subsequent months-long controversy brought into relief fears on the part of one group of African 
American parishioners. They worried that the Afrocentric identity and liturgical style of the parish could be diluted or lost, and their fear was exacerbated by the aging of the Black Catholic community in Los Angeles and its shrinking number of specifically identified parishes. The surging numbers of Latino Catholics both in the neighborhood and across the city played a role. Today Hispanic Catholics constitute $72 \%$ of all Catholics in Los Angeles and Ventura Counties while Black Catholics constitute 4\% (Phillips 2017). According to census data collected by the Department of City Planning, the Black and African American population of Los Angeles declined by more than 100,000 people from 1990-2010 while the Hispanic population increased by more than four times that amount (L.A. City Planning Department 2005, 2011). One Latino parish council member recounted how an African American friend told him that Latinos would "displace" (in Spanish, desplazar) African Americans at the parish (interview, March 13, 2013).

All this erupted, of course, against the backdrop of a history of racial discrimination against Black Catholics by whites in Catholic Los Angeles, as well as older parishioners' memories of moving from the Jim Crow South to Los Angeles in the 1940s and 50s (Knox 2008). African American Catholics had never been more than a small minority among L.A. Catholics. Latino Catholics, of course, have their own parallel history of discrimination in the Catholic world of Los Angeles, including, for example, the establishment of separate, often inadequately resourced mission parishes (Burns 1994). Yet this long history would remain largely invisible to recent immigrants, and the future of Latino Catholicism appeared brighter with a growing population and a Mexican immigrant as the archbishop. In short, African American Catholics at Holy Nativity felt a kind of existential threat to their ownership of both the parish and Catholicism in Los Angeles in general, a threat assessment that Latinos did not share. In the end, the white priest pastor called upon the bishop to adjudicate the controversy. The bishop insisted that the word Hispanic had to stay, that the mission statement had to reflect who currently was involved in the parish (interview, July 27, 2012). The controversy came to an end.

\section{Devotional Space and Equitable Co-ownership}


Of the three parishes in this study, the one with the least ethnic and racial tension appeared to be Queen of Heaven, the megaparish in a Latino suburb. The huge parish festival was universally described as drawing participation and cooperation across racial, ethnic, and language communities. While the Filipino community was described as feeling neglected under a previous pastor, members of that community retained a strong sense of their place at the parish and connection to its spaces.

Even the worship space reflected a certain balance of ownership among the communities. Catholic churches often have side chapels, separate rooms where people pray alone or engage in popular religious devotions separately from the official liturgical worship. At Queen of Heaven, there were two such chapels, both in the back of the church, each devoted to the popular religious concerns of one of the groups at the parish. The larger chapel bore the name and contained an image of the Virgin of Guadalupe, the well-known Mexican image of the Virgin Mary. That chapel remained packed around the Spanish masses, though Filipinos would also kneel there to pray. A Filipina confided with pride that a relative's wake service took place there. The other chapel was the "All Saints chapel," and it contained a statue of the Filipino saint Lorenzo Ruiz, a painted portrait of the Virgin Mary as Our Lady of Perpetual Help (an international devotion popular among Filipinos), and the more contemporary image of Divine Mercy—Jesus with multicultural rays of light emerging from his heart. Nearby on the wall was an image of Sister Faustina Kowalska, a Polish saint and the founder of the Divine Mercy devotion. A Filipina tour guide referred to this chapel semi-facetiously as "the Filipino room," and we observed many Filipinos entering the space, though Latinos also occasionally prayed there after the Spanish mass.

Conversations at Queen of Heaven surfaced the cultural commonalities between Latino and Filipino traditions of popular religious devotion. The young Latina youth minister said, "And so I think in our devotion, we ultimately are devout in the same way, but the way we honor is different. Like, I always love when they have the Filipino celebrations, there's always like music and dancing, which is the same with Hispanic culture but the way they do it is different" (interview, July 17, 2012). During our visit to Queen of Heaven, several people described an evolving cooperation between Spanishspeaking Hispanic and Filipino parishioners for the celebration of Divine Mercy, a globally popular novena (nine-day prayer) with roots in Poland but 
previously celebrated separately by Hispanic and Filipino parishioners at Queen of Heaven. Fr. Tito, a Filipino priest popular in the Latino community for his vivacious ways and fluent Spanish, coordinated a dual language committee planning the novena, mass, and party, all at the direction of the pastor. By several accounts, the cooperation was rocky at first but improved over time, despite a language barrier.

These brief accounts from the three different parishes demonstrate the impact of several factors on felt ownership of parish space. Among these are size, relative social status, and tenure in the parish. At Holy Nativity, the mission statement controversy clearly demonstrated the African American community's stronger sense of felt ownership over the parish; the controversy arose between factions within that community, each certain that it had the right to decide who was represented in the symbolic space of the bulletin's mission statement. That stronger sense of ownership manifested itself in more subtle ways. For example, during observations at the parish, we noted the way in which liturgical customs that serve as identity markers in African American worship - colorful choir robes, the recognition of birthdays and anniversaries during announcements-were also found at the Spanish mass, though sometimes tepidly received.

This stronger felt ownership corresponded to advantages in terms of size, tenure at the parish, and social status. The African American community attending mass at Holy Nativity was much larger than the Latino community, even though the neighborhood was now 58.5\% Latino and only 35.5\% Black (Statistical Atlas 2015). Earlier census reports and the aging character of the Black population today, however, indicated a historically African American neighborhood (Los Angeles Times Data Desk 2010; Statistical Atlas 2015). For several decades, the African American community had dominated lay parish leadership teams and groups, despite the Latino community's decades of presence at the parish (Knox 2008). According to multiple sources within the parish, many African American parishioners came to mass from outside the poor neighborhood, an indication of upward mobility and greater socioeconomic status. The surrounding businesses were mostly African American owned, and the local political leaders were African American. 
Similarly, at St. Martin de Porres, the English-speaking community possessed greater size and social status, though the question of tenure proved more complicated. The several English masses had much greater Sunday attendance overall. English speakers tended to live in the more affluent local area, where the median income was over a hundred thousand dollars (American Community Survey of the U.S. Census, 2011-2015). Most English speakers were of much higher socioeconomic status than Spanish speakers, who generally lived some distance away in working class suburbs-the local area was now $8.4 \%$ Hispanic and $80.9 \%$ white (U.S. Census 2010). The Spanish-speaking tour guide recounted that some Spanish-speaking parishioners had taken over ownership of houses willed to them by the elderly Anglos they served as housekeepers. This subversive tale points to the way in which status was reinforced by local economic patterns. Most of the service work in the area-lawn care, housekeeping, restaurant work-was done by working class Latinos, many of them immigrants.

Some of this asymmetrical dynamic was mitigated by the history of the parish as a Mexican mission, a history which seems to have lasted a few decades beginning in the 1920s. I witnessed the renewal of vows of a highly regarded elderly couple whose family had come during those early years. Indeed, some Latino parishioners retained family connections to the Mexican mission era, though that era had long passed, and many now identified with the dominant culture and spoke only English. No one we spoke with expressed any resistance to the presence of a Spanish-speaking community, and several evinced pride in the parish's multicultural identity. Nevertheless, the dramatic differences in social status appear to have shaped the differences in felt ownership during the renovation process, both the confident involvement of English-speaking leaders and the "subdued" participation of the Spanish speakers.

The situation at Queen of Heaven appears even more complex. Interviews and observation did not surface a clearly privileged group in terms of felt ownership. Yet in terms of numbers, the parish remained overwhelmingly Latino, like the suburb in which it was located. Filipinos functioned as a relatively tiny minority, though they had a long tenure in the parish. This tenure gave them time and opportunity to purchase devotional statues and images for the All Saints chapel. The small Filipino community also had more persons with professional jobs, and the social status that goes 
with them. Accordingly, they came to parish life with a confidence disproportionate to their numbers. Cultural similarities in popular religious traditions, rooted in a common Spanish heritage, also facilitated a more equal sense of co-ownership of devotional space between the groups.

At Queen of Heaven, however, mention must also be made of the impact of clergy leadership on this shared sense of felt ownership. The priest pastor consistently and publicly insisted on the equality of all three communities in parish life-Spanish-speaking Latino, English-speaking Latino, and Filipino. This was confirmed by sources across the different groups, and I have argued elsewhere how the pastor's vision of equal partnership among the groups (and his interventions to enforce that vision) played a strong role in producing a more egalitarian parish landscape (Hoover 2017). He also had specific influence over the way in which felt ownership was manifested in popular religious devotion. He had no qualms about authorizing the purchase and installation of new statues and religious art on the physical plant, an approach that allowed Filipinos to sustain a greater devotional presence than their numbers might indicate. Finally, he specifically instructed the Latino and Filipino communities to cooperate around a common Divine Mercy celebration under the guidance of his assistant, Fr. Tito. All this figured as part of his strategy to demonstrate that there was no favoritism in the parish, and all of the communities belonged to a larger common project of parish life (Hoover 2017).

In contrast, at St. Martin de Porres, the priest pastor's role seemed to subtly limit rather than equalize parishioners' sense of felt ownership. He dominated the process of church renovation and did not appear to doubt his authority to do so. He invited the architect who supervised it, and by his own account he directed much of what emerged. Even the largely English-speaking lay leaders who participated and paid for the renovation played a more subordinate role, though none of them complained about this. Though this pastor spoke some Spanish, he had a significantly weaker role in the Spanishspeaking community, which was served by a priest from Mexico the pastor had himself recruited. This weaker role was exacerbated by his need to cultivate more affluent donors for the renovation of the church, who largely came from the English-speaking community. It may also have contributed to 
the disconnect between the Spanish-speaking community and the renovation he dominated.

At Holy Nativity, the pastor himself experienced limits to his felt ownership over the parish. In the midst of the church bulletin controversy, he deemed it imprudent for him as a white pastor to try to impose his own solution on his largely African American flock. He was, in a certain sense, less of a felt owner than that flock. Such limits did not apply the bishop, however; pastor and parishioners presumed he had the right to decide the issue, and his decision, while not universally appreciated, was accepted as final. The bishop himself reminded the parish pastoral council of the limits of their ownership over the parish; he noted that in a few years, if a different set of racial and ethnic groups worshipped there, those groups would have to be identified in the bulletin space (interview, July 27, 2012).

\section{Conclusion}

At these three parishes, subtle asymmetries between racial, ethnic, or language groups had a clear impact on the sense of felt ownership each group had within the parish. Sheer demographics played a role, as parishioners from much larger communities reflexively felt a greater sense of ownership. The historical tenure of communities with the parishes had some impact as well. At Holy Nativity, the African American community's long presence played a role in their dominant ownership over the parish, though their strong investment in the symbolic value of the African American cultural identity of the parish probably played an even greater role. For other communities, historical tenure had diminishing returns in the face of numbers and socioeconomic status. At St. Martin de Porres, a handful of elderly Latino parishioners had been there for many decades, but their descendants had assimilated into the much larger English-speaking community, ascendant in the parish for a long time. More recent immigrants from Mexico, a smaller community with lower socioeconomic status, appeared to have a more limited felt sense of ownership. At all three of the parishes, socio-economic status had a strong impact on the relative sense of felt ownership at the parish, a finding that confirms my own earlier research at All Saints (Hoover 2014). The impact of priests and the bishop on felt ownership across the three parishes serves as a reminder of the considerable authority of priests in Catholic parishes still, 
despite de facto congregationalism and the Vatican II emphasis on lay leadership.

Case study ethnography at three shared parishes in the same region of the country, no matter how thorough or insightful, has significant limits in producing generalizable conclusions about what felt ownership is, or its relationship to the societal power dynamics associated with demographic dominance, historical tenure, relative social status, or any other factor. At the very least, however, these results suggest that the social processes that people think of as constituting ownership are more complex than legal or economic property rights. In Roman Catholic church law, the bishop and priest pastor have full authority over church property, and in civil law in most U.S. states, the bishop as corporation sole retains full rights to decree how parish property may be used or sold, even if that authority is often delegated to a priest pastor. Yet the people at these three parishes clearly saw themselves as possessing a sense of ownership over parish life and property, and they acted accordingly, even if they implicitly or explicitly recognized the greater right of ownership of their pastor or bishop.

Other studies (Bridger and Maines 1998; Maines and McCallion 2004; Seitz 2011) imply that this sense of "felt ownership" has found support in internal church movements that promote the ecclesial responsibility of ordinary congregants, such as, for Catholics, the theology of baptismal priesthood and lay involvement associated with the Second Vatican Council. But how might "felt ownership" unfold in religious communities where the polity is unambiguously congregational in character and church property is legally owned by lay trustees? Sociologists argue that in the United States, governmental legal structures and cultural traditions favor the kind of lay leadership that promotes felt ownership, even if the explicit governance structures of religious traditions do not (Warner 1994). Does the kind of state church tradition found in Germany or the United Kingdom then inhibit the development of a sense of felt ownership? Is it only likely to develop within the faith communities of minority religious communities in such contexts? Further research in such contexts would help clarify whether or not "felt ownership" has generalizable potential for local faith communities across denominational and geographic contexts. 
In the entirely different context of Mediterranean shrines shared by Christians, Muslims, and Jews, the historical anthropologist Maria Couroucli argues: "Sharing is not an everyday practice: it is an exceptional modality, inscribed in local tradition, and as such is related to borders and margins" (2012: 6). Accordingly, the research she chronicles describes how "unlike normal times in towns and villages, sacred time and space transcend frontiers and social barriers, facilitating-and legitimating-contacts between individuals who would otherwise not meet in the public sphere" (Idem: 7). In a sense, joint felt ownership spontaneously occurs in such liminal space. But the demographic transformations associated with global migration have a way of turning ordinary spaces into borders and margins. Shared Catholic parishes like the ones presented here are far from exceptional in today's U.S. context, and the encounters between racial, ethnic, and language groups that they facilitate occur over and over again, in "normal times." In these normal times, power dynamics intrude that make felt ownership complex and ambiguous. These pages have made an initial attempt at deciphering some of the factors involved, but much more needs to be done. In world increasingly shaped by demographic transformations, Catholic shared parishes may prove a helpful laboratory for sorting out which groups feel and take responsibility for the institutions of our societies, which feel excluded from doing so, and why.

\section{Bibliography}

American Community Survey (2011-2015). “Quickfacts.” United States Census Bureau. https://www.census.gov/quickfacts/CA. Accessed September 2, 2017.

Bridger, J. C., and D. R. Maines. (1998). “Narrative Structures and the Catholic Church: Closings in Detroit." Qualitative Sociology 21 (3): 319-340.

Burns, J. M. (1994). "The Mexican Catholic Community in California." In Mexican Americans and the Catholic Church, 1900-1965, edited by J. P. Dolan and Gilberto M. Hijosa. Notre Dame, IN: Notre Dame University Press, p. 129-233. 
Cadge, W. (2008). "De Facto Congregationalism and the Religious Organizations of Post-1965 Immigrants to the United States: A Revised Approach. "Journal of the American Academy of Religion 76 (2): 344-374.

Carruthers, B. G., and L. Ariovich. (2004). "The Sociology of Property Rights." Annual Review of Sociology 30: 23-46.

Coriden, J. A., T. J. Green, and D. E. Heintschel. (1985). The Code of Canon Law: $A$ Text and Commentary. New York: Paulist Press.

Couroucli, M. (2012). "Introduction: Sharing Sacred Places-A Mediterranean Tradition." In Sharing Sacred Spaces in the Mediterranean: Christians, Muslims, and Jews at Shrines and Sanctuaries. Bloomington: Indiana University Press, p. 1-9.

Dane, P. (1998). "The Corporation Sole and the Encounter of Law and Church." In Sacred Companies: Organizational Aspects of Religion and the Religious Aspects of Organizations. Edited by N.M. Demerath, Peter Dobkin Hall, Terry Schmitt, and Rhys A. Williams. New York: Oxford University Press, p. 50-61.

Department of City Planning for the City of Los Angeles. (2005). "City of Los Angeles Census 2000 Citywide Statistics." http://cityplanning.lacity.org/ Accessed August 9, 2017.

Department of City Planning for the City of Los Angeles. (2011). "City of Los Angeles Census 2010 Citywide Profile." http://cityplanning.lacity.org/. Accessed August 9, 2017.

Dolan, J. P. (1992). The American Catholic Experience. Notre Dame, IN: Notre Dame University Press.

Garces-Foley, K. (2007). Crossing the Ethnic Divide: The Multiethnic Church on a Mission. New York: Oxford University Press.

Hoover, B. C. (2014). The Shared Parish: Latinos, Anglos, and the Future of U.S. Catholicism. New York: NYU Press.

—. (2017). "No Favoritism: Effective Collaborative Leadership Practices in Multicultural Parishes." In Collaborative Parish Leadership: Contexts, 
Models, Theology, edited by W. A. Clark and D. Gast. Lanham, MD: Lexington, p. 103-124.

Knox, A. (2008). Blazing an African American Trail: The History of Black Catholics in the Archdiocese of Los Angeles. Minneapolis: Mill City Press.

Los Angeles Times Data Desk. (2010). Mapping L.A. website. http://maps.latimes.com/neighborhoods/. Accessed August 9, 2017.

Maines, D. R., and M. J. McCallion (2004). "Research Note: Evidence of and Speculations on Catholic de facto Congregationalism." Review of Religious Research 46 (1): 92-101.

Marti, G. (2004). A Mosaic of Believers: Diversity and Religious Innovation in a Multiethnic Church. Bloomington, IN: Indiana University Press.

O'Toole, J. M. (2008). The Faithful: A History of Catholics in America. Cambridge, Massachusetts, Harvard University Press.

Pew Research Center. (2015). America's Changing Religious Landscape. Washington, DC: Pew Forum for Religious Research.

Phillips, B. A. (2017). "Breakdown of Each Religion by Race/Hispanic Origin for Five Counties in Southern California Association of Governments." Unpublished statistics collected for Martin Gang Institute Study of Interreligious Dialogue, Loyola Marymount University.

Reeve, A. (1986). Property. Atlantic Highlands: Humanities Press International.

Seitz, J. C. (2011). No Closure: Catholic Practice and Boston's Parish Shutdowns. Cambridge, Massachusetts, Harvard University Press.

Statistical Atlas. (2015). "Overview of Los Angeles, California (city)." Statistical Atlas website. https://statisticalatlas.com/metroarea/California/Los-Angeles/Overview. Accessed August 9, 2017.

U.S. Census. (2010). "Quickfacts." United States Census Bureau. https://www.census.gov/quickfacts/CA. Accessed August 9, 2017.

Wellmeier, N. J. (1998). “Santa Eulalia's People in Exile: Maya Religion, Culture, and Identity in Los Angeles." In Gatherings in Diaspora: Religious Communities and the New Immigration, edited by R. S. Warner and J. G. Wittner. Philadelphia: Temple University Press, p. 97-122. 
Warner, R. S. (1998). "Immigration and Religious Communities in the United States." In Gatherings in Diaspora: Religious Communities and the New Immigration, edited by R. S. Warner and J. G. Wittner. Philadelphia: Temple University Press, p. 3-34.

—. (1993, 2005). "Work in Progress: Toward a New Paradigm for the Sociological Study of Religion in the United States." In A Church of Our Own: Disestablishment and Diversity in American Religion, edited by R. S. Warner. New Brunswick, NJ: Rutgers University Press, p. 18-62.

- (1994). "The Place of the Congregation in the Contemporary American Religious Configuration." In New Perspectives in the Study of Congregations, vol. 2 of American Congregations, edited by J. P. Wind and J. W. Lewis. Chicago: University of Chicago Press, p. 54-99. 